\title{
The demand of modern varieties of winter wheat to mineral nutrition
}

\author{
Miroshnychenko M. ${ }^{1}$, Panasenko Ye. ${ }^{2}$, Zvonar A. ${ }^{3}$, Leonov O. ${ }^{4}$, Halasun Yu. ${ }^{5}$, Havryliuk V. ${ }^{6}$ \\ ${ }^{1-3}$ National Research Center "Sokolovsky Institute of Soil Science and Agrochemistry» \\ 4, Tchaikovskyi Str., Kharkiv, 61024, Ukraine \\ ${ }^{4} \mathrm{~V}$.Ya. Yuriev Institute of Plant Breeding of NAAS \\ 142, Moskovskyi Prospekt, Kharkiv, 61060, Ukraine \\ ${ }^{5}$ LLC Research and Production Firm "Urozhai» \\ 193, Blagovisna Str., Cherkasy, 18000, Ukraine \\ ${ }^{6}$ Polissia Research Station of NRC «Sokolovsky Institute of Soil Science and Agrochemistry» \\ 35, Shevchenko Str., Lutsk, 43001, Ukraine \\ e-mail: ${ }^{1}$ ecosoil@meta.ua, ${ }^{2}$ panasenko-evgeniy777@ukr.net, ${ }^{3} z$ vonaranastasia@gmail.com \\ 4oleleo@i.ua, ${ }^{5}$ yu.galasun@mhp.com.ua, ${ }^{6}$ gavrilyuk-v@ukr.net \\ ORCID: ${ }^{10000-0003-2830-5933, ~}{ }^{2} 0000-0002-5248-0179,{ }^{3} 0000-0002-4620-7125,{ }^{4} 0000-0001-9191-8658$, \\ ${ }^{5} 0000-0002-9905-4353,{ }^{6} 0000-0003-3923-0842$
}

Goal. Generalization of the results of experimental studies of the content of nutrients in grain and straw of winter wheat varieties currently grown in Ukraine. Methods. The research was carried out during 2016-2020 at two objects of variety testing in the forest-steppe zone of Ukraine, on production fields in Western Polissya, Right-Bank and Left-Bank of Forest-Steppe, with statistical analysis of chemical-analytical data. Results. According to the generalization of data on 167 plots of winter wheat cultivation of modern varieties, accumulation of nutrients in grain and straw differs from parameters that were revealed before. Modern varieties are characterized by a narrower ratio of $\mathrm{N}$ : P2O5 in the grain (1: 0.30), which differs from the previously developed standards (1: 0.34-0.35), as well as a much higher accumulation of potassium in straw. The content of nutrients in grain has more stable parameters than in straw. High variability of micronutrient composition of grain and straw, especially cobalt and iron, has been found. It is proposed to use as normative not arithmetic means, but geometric means. Similar features of the chemical composition of grain and straw were at all objects of the study. Conclusions. Average parameters of nutrient uptake in winter wheat modern varieties are (kg/t): for grain $\mathrm{N}$ - 21.6, $\mathrm{P}_{2} \mathrm{O}_{5}-6.5, \mathrm{~K}_{2} \mathrm{O}-4.6$, for straw - 4.9, 1.1 and 17.5 respectively. Average parameters of micronutrient uptake in winter wheat modern varieties are $(\mathrm{mg} / \mathrm{kg})$ : for grain - Zn 19, Co 0.51, Fe 37, Mn 30, Cu 2.1, for straw - Zn 1.8, Co 0.52, Fe 27, Mn 12, Cu 0.6.

Key words: NPK, microelements, grain, straw, remote standards, variability, variety specificity, strain testing plots.

DOI: https://doi.org/10.31073/agrovisnyk202104-04

Winter wheat is the most demanding crop among cereals in terms of mineral nutrition. Due to breeding progress, modern varieties of winter wheat have a high level of nitrogen uptake and its reutilization in plants, that is often accompanied by increased concentrations of other nutrients [1-2]. It is proved that these properties of modern varieties are occurred mainly under the high fertilizing, while old varieties show more stable yield on the lack of nutrients [3]. However, due to lack of information, the peculiarities of the nutrition of new varieties of wheat are not taken into account when agronomists design a fertilizer system, as suggested by E. Klimashevsky 30 years ago [4]. Genetic features of enzymatic systems, absorption and photosynthesis in different varieties of winter wheat require appropriate forms and doses of fertilizers [3, 5-6], but also lead to different resilience to the acid $\mathrm{pH}$ [7], salinization [8-9] and other affecting factors in terms of nutrients uptake. Therefore, it is necessary to periodically update the regulatory framework for the development of adaptive farming systems, including fertilizer systems.

In 2014, a draft of Resolution of the Cabinet of Ministers of Ukraine "Regulatory indicators of nutrient removal by crops" [10] was developed in accordance with Articles 30 and 32 of the Law of Ukraine "On Land Protection" and the action plan of the Ministry of Agrarian Policy of Ukraine. This regulatory act provides standards of NPK content per unit of crop yield by nature zones (Table 1).

\section{Standards for nutrient removal with the harvest of winter wheat (according [10])}

\begin{tabular}{|c|c|c|c|c|c|c|}
\hline \multirow{3}{*}{ Nature zones } & \multicolumn{6}{|c|}{ NPK content per 1 ton of crop yield, kg } \\
\hline & \multicolumn{3}{|c|}{ grain } & \multicolumn{3}{|c|}{ straw } \\
\hline & $\mathrm{N}$ & $\mathrm{P}_{2} \mathrm{O}_{5}$ & $\mathrm{~K}_{2} \mathrm{O}$ & $\mathrm{N}$ & $\mathrm{P}_{2} \mathrm{O}_{5}$ & $\mathrm{~K}_{2} \mathrm{O}$ \\
\hline Forest (Polissya) & 22,0 & 7,7 & 5,1 & 5,0 & 1,7 & 9,8 \\
\hline Forest-Steppe & 23,5 & 7,9 & 6,3 & 5,4 & 1,9 & 10,9 \\
\hline Steppe & 21,7 & 7,9 & 5,7 & 4,8 & 1,8 & 11,5 \\
\hline Average & 22,4 & 7,8 & 5,7 & 5,1 & 1,8 & 10,7 \\
\hline
\end{tabular}


Due to the fact that the abovementioned project has not yet been approved, researchers use other values of NPK removal with grain and straw of winter wheat. In particular, G. Hospodarenko gives the following values of removal per 1 ton of grain: $\mathrm{N}-22.7 \mathrm{~kg}, \mathrm{P}_{2} \mathrm{O}_{5}-8.0 \mathrm{~kg}, \mathrm{~K}_{2} \mathrm{O}-5.5 \mathrm{~kg}$, and per 1 ton of straw $-5.7 \mathrm{~kg}, 1.9 \mathrm{~kg}$ and $10.7 \mathrm{~kg}$, respectively [11]. The method of calculating the balance of NPK by NSC "ISSAR named after ON Sokolovsky" uses slightly different standard parameters in a straw: $\mathrm{N}-5.1 \mathrm{~kg}, \mathrm{P}_{2} \mathrm{O}_{5}-1.6 \mathrm{~kg}, \mathrm{~K}_{2} \mathrm{O}-9.9 \mathrm{~kg}$ [12]. M. Gorodnyi et al. have mentioned higher nutrient content in grain, namely: $\mathrm{N}-2.50 \%, \mathrm{P}_{2} \mathrm{O}_{5}-0.85 \%$, $\mathrm{K}_{2} \mathrm{O}-0.65 \%$, and for straw $-0.50 \%, 0.20 \%$ and $0.90 \%$, respectively [13]. Unfortunately, all the above indicators refer mainly to varieties that were in crop production more than 20-30 years ago, and it is currently unknown to what extent they coincide with the requirements of modern wheat varieties.

Little is known about the micronutrient composition of grain products. Modern farming systems in Ukraine are usually deficient in the balance of micronutrients [14]. According to D. Garvin and R. Welch, genetic improvements in the United States have led to a decrease in the concentration of $\mathrm{Fe}, \mathrm{Zn} \mathrm{Se}$ in grain, although yields are increasing [15]. On the other hand, the study of K. Hamner et al. [2], as well as Z. Svecnjak et al. [16] show that the increase in nitrogen uptake during the wheat growing season is also accompanied by a greater accumulation of $\mathrm{Fe}, \mathrm{Zn}, \mathrm{Mn}, \mathrm{Cu}$ and $\mathrm{B}$ in plants.

The purpose of this article is to generalize results of experimental research regarding nutrients content in grain and straw of winter wheat varieties currently grown in Ukraine.

Methods. The research was carried out during 2016-2020 at two objects of variety testing in the foreststeppe zone of Ukraine and by expeditionary research on crop production fields in Western Polissya, RightBank and Left-Bank Forest-Steppe.

24 winter wheat varieties in 2016 and 36 winter wheat varieties in 2017 were studied at the demonstration and research field of LLC "PRF "Urozhay" (Korsun-Shevchenkivskyi district of Cherkasy region), where Phaeozems predominate in soil cover. Particularly, it were studied varieties by German breeding - Etana, Patras, Matrix, Kombin, Arctis (Deutsche Saatveredelung AG), Skagen, Torild (SAATEN UNION); Austrian breeeding - Panonicus, Tacitus, Fidenius, Balitus (Saatzucht Donau); Czech breeding - Bodicek, Bordotka, Daria (RAGT Semences), Croatian breeding - Annica, Mandica (Zagreb Bc Institute), and Ukrainian breeding - Svitanok Myronivsky (Myronivsky Wheat Institute named after V.M. Remesla), Chorniava (Institute of Plant Physiology and Genetics of the National Academy of Sciences of Ukraine) .

Four varieties that are a national standards of Ukraine - Rozkishna (V. Yuriev Institute of Plant Breeding). Yuriev), Bunchuk (Breeding and Genetics Institute), Smuglyanka and Podolyanka (Institute of Plant Physiology and Genetics of the National Academy of Sciences of Ukraine), as well as 8 varieties of foreign breeeding the above-mentioned Balitus, Arctis, Matrix, Annitsa, Manditsa, Bodicek and Daria were studied at the research field of the Plant Production Institute named after V.Ya. Yuriev NAAS (Kharkiv district of Kharkiv region, 20182020) on Chernozem haplic.

The peculiarities of winter wheat nutrient uptake were studied during the expeditionary research in Western Polissya on Luvisols and Phaeozem, in the Right-Bank Forest-Steppe - on Phaeozems, Chernozem luvic, in the Left-Bank Forest-Steppe - on Phaeozems, Chernozem luvic and haplic. Samples were taken random, and the agrochemical properties of soils differed greatly in some cases.

Samples of grain and straw were taken before harvest in 3 repetitions, each sample consisted of 15-20 plants. The content of nitrogen, phosphorus and potassium in grain and straw was determined by the method of wet chemistry ashing with analytical ending on the spectrophotometer SF-4 and flame photometer CL-22D, the content of trace elements - on atomic absorption spectrophotometers AANALYST 400 and Saturn-76. During 2016-2020, grain and straw were analyzed in 167 plots, which differed in soil type, level of nutrient supply and fertilizer. Data analysis was performed by Statistica 10.

Results. Generalization of all data on the content of macro- and microelements in grain and straw of winter wheat in 2016-2020 allows to take into account not only genetically determined features of modern varieties, but also due to soil-climatic, weather conditions and fertilizers, which differed significantly in some cases. The sample met the criteria of Shapiro-Wilkes normality in terms of NPK content in grain (W $=0.98-0.99 ; p=0.16$ 0.56). The main statistical characteristics of NPK content are shown in the table 2.

\section{Main statistics of NPK content in grain and straw in $2016-2020$ ( $n=167)$}

\begin{tabular}{|c|c|c|c|c|c|c|}
\hline \multirow{2}{*}{$\begin{array}{c}\text { Part of } \\
\text { yield }\end{array}$} & Nutrients & mean & minimum & maximum & $\begin{array}{c}\text { standard } \\
\text { error }\end{array}$ & $\begin{array}{c}\text { Coefficient } \\
\text { of variation }\end{array}$ \\
\cline { 2 - 7 } & $\mathrm{N}$ & 2,16 & 1,43 & 2,97 & 0,32 & 15 \\
\hline \multirow{3}{*}{ Grain } & $\mathrm{P}_{2} \mathrm{O}_{5}$ & 0,65 & 0,39 & 0,88 & 0,09 & 13 \\
\cline { 2 - 7 } & $\mathrm{K}_{2} \mathrm{O}$ & 0,46 & 0,33 & 0,58 & 0,05 & 11 \\
\hline \multirow{3}{*}{ Straw } & $\mathrm{N}$ & 0,49 & 0,16 & 1,29 & 0,19 & 38 \\
\cline { 2 - 7 } & $\mathrm{P}_{2} \mathrm{O}_{5}$ & 0,11 & 0,04 & 0,53 & 0,08 & 70 \\
\cline { 2 - 7 } & $\mathrm{K}_{2} \mathrm{O}$ & 1,75 & 0,49 & 2,94 & 0,50 & 29 \\
\hline
\end{tabular}

According to experimental data, modern varieties of winter wheat are characterized by average parameters of nutrients uptake from 1 ton of grain: $\mathrm{N}-21.6 \mathrm{~kg}, \mathrm{P}_{2} \mathrm{O}_{5}-6.5 \mathrm{~kg}, \mathrm{~K}_{2} \mathrm{O}-4.6 \mathrm{~kg}$, and from 1 ton of straw -4.9 $\mathrm{kg}, 1.1 \mathrm{~kg}$ and $17.5 \mathrm{~kg}$, respectively. With the exception of potassium in straw, these values are lower than those given in [10-13], but very well coincide with the data of recent studies [17-18]. In our opinion, the lower 
content of nutrients in the final product is due to their more efficient use in modern varieties of wheat and a high level of their yield. Another feature of modern varieties is a narrower ratio of $\mathrm{N}: \mathrm{P}_{2} \mathrm{O}_{5}=1: 0.30$ that differ from 1:0.34-0.35, as previously envisaged.

The content of nutrients in straw is less stable, because it depends more on the completeness of remobilization and other influencing factors. The highest variation was for phosphorus, its content in straw varied from $0.04 \%$ to $0.53 \%$. On average, straw of modern varieties also contains less nitrogen and phosphorus but much more potassium, probably due to the peculiarity of varieties of European breeding [19]. The fact that the differences in the chemical composition of grain and straw is not a random phenomenon, confirmed by statistical analysis of subordinate data samples based on the results of surveys of production fields in 2016-2017 ( $n=72$ ), demonstration and research field of LLC "RPF Urozhay" in 2016-2017 ( $n=60)$, and the research field of the Plant Production Institute named after V.Ya. Yuriev NAAS in 2018-2020 $(n=35)$.

a) grain

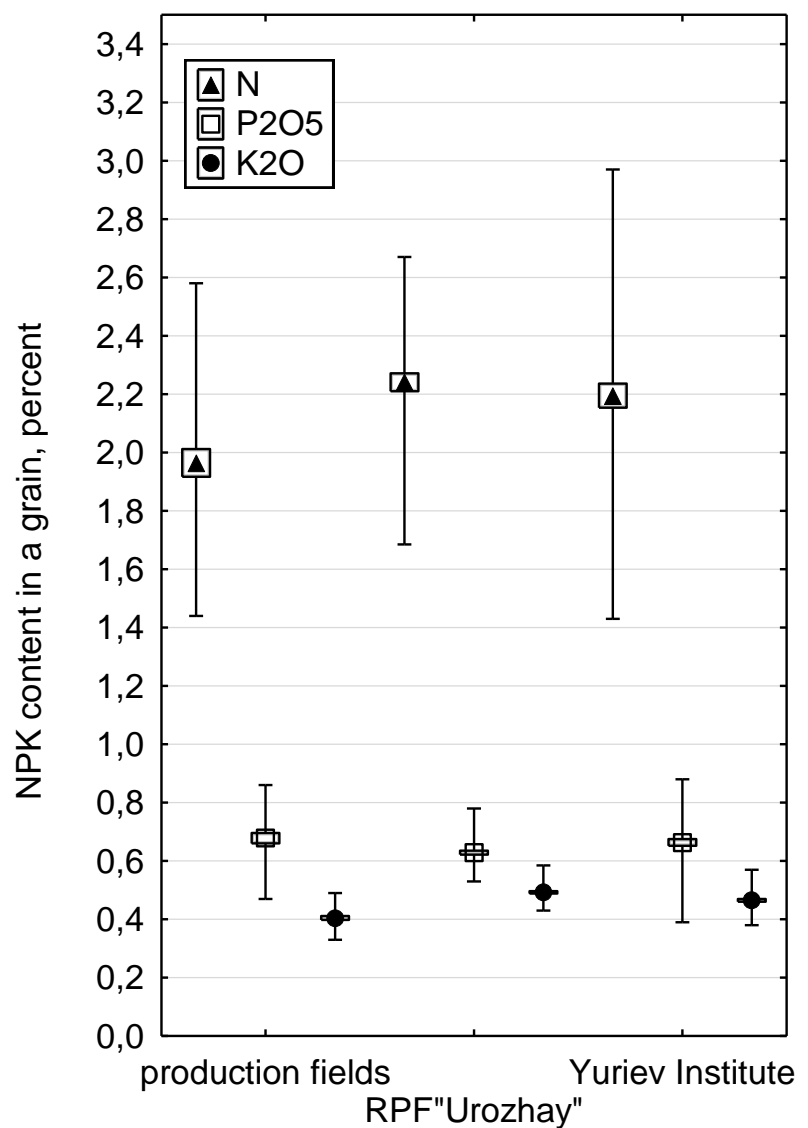

b) straw

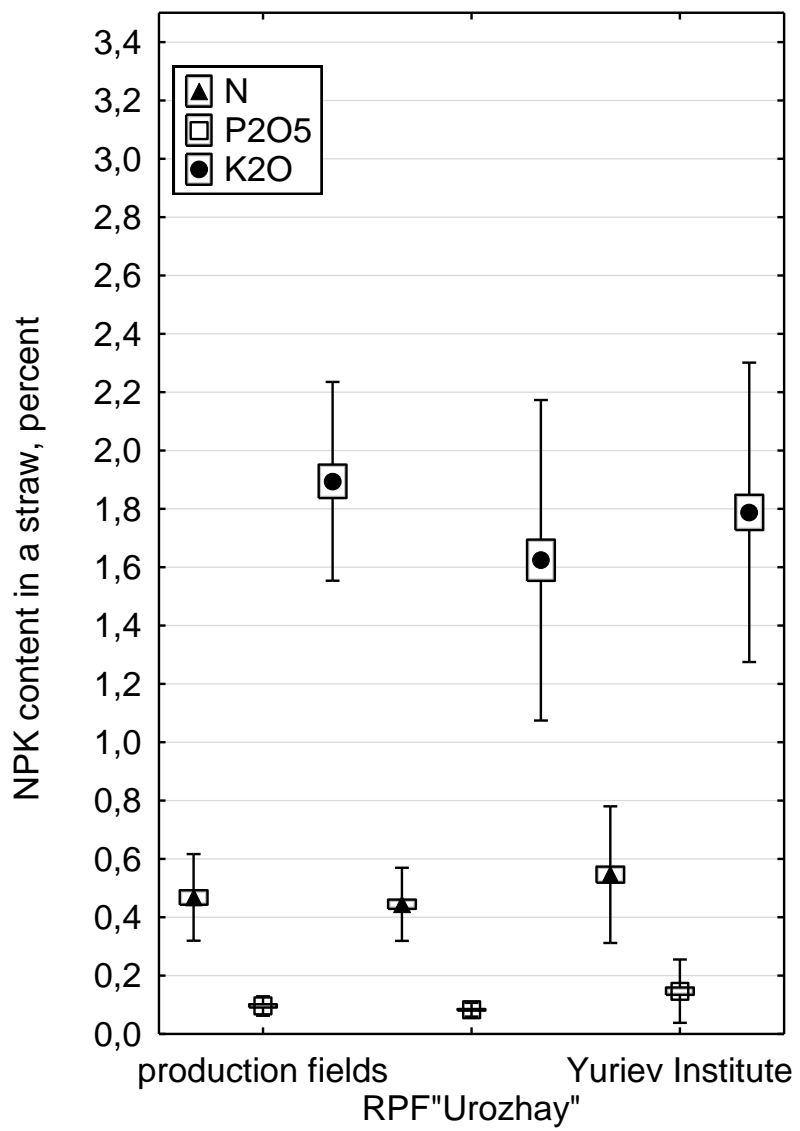

NPK content in winter wheat grain (a) and straw (b) at the study sites in 2016-2020 (mean values, standard error and standard deviation are indicated)

According to the graph, the average nitrogen content in grain was the highest at the demonstration and research field of LLC "RPF "Urozhay", where varieties of foreign breeding have dominated, and the lowest content was at the research field of the Plant Production Institute named after V.Ya. Yuriev NAAS, where a third of all studied varieties had a domestic origin. The average potassium content in straw in all samples exceeded the parameters mentioned in [10 - 13]. These differences in the content and ratio of NPK in winter wheat are quite conditional, as it is clear how much it depends on the environment conditions and technology. The information from various sources have confirmed above conclusion (table 3 ).

\section{The content of NPK in grain and straw of winter wheat according to different sources}

\begin{tabular}{|l|c|c|c|c|c|c|}
\hline \multirow{2}{*}{ Researches } & \multicolumn{5}{|c|}{ Content in dry material, \% } \\
\cline { 2 - 7 } & \multicolumn{5}{|c|}{ grain } & \multicolumn{2}{c|}{ straw } \\
\cline { 2 - 7 } & $\mathrm{N}$ & $\mathrm{P}_{2} \mathrm{O}_{5}$ & $\mathrm{~K}_{2} \mathrm{O}$ & $\mathrm{N}$ & $\mathrm{P}_{2} \mathrm{O}_{5}$ & $\mathrm{~K}_{2} \mathrm{O}$ \\
\hline $\begin{array}{l}\text { J.M. Clarke et al., } \\
1990 \text { [20] }\end{array}$ & $1,94-2,90$ & $0,69-0,96$ & - & - & - & - \\
\hline $\begin{array}{l}\text { P. Khan et al., 2008 } \\
{[21]^{*}}\end{array}$ & $1,44-2,73$ & $0,34-0,70$ & - & $0,16-0,61$ & $0,021-0,089$ & -- \\
\hline $\begin{array}{l}\text { V.V. Ivanina, 2013 } \\
{[22]}\end{array}$ & $2,40-2,59$ & $0,80-1,00$ & $0,55-0,81$ & $0,55-0,74$ & $0,21-0,24$ & $1,04-1,33$ \\
\hline
\end{tabular}




\begin{tabular}{|l|c|c|c|c|c|c|}
\hline $\begin{array}{l}\text { V. Kovačević et al., } \\
2013 \text { [23] }\end{array}$ & - & $0,90-1,00$ & $0,55-0,58$ & - & - & \\
\hline $\begin{array}{l}\text { Y.A. Rangel et al., } \\
2013 \text { [24] }\end{array}$ & $1,66-1,90$ & $0,71-0,85$ & - & $0,43-0,70$ & $0,22-0,73$ & - \\
\hline $\begin{array}{l}\text { Ya.S. Filimonchuk, } \\
2014 \text { [25] }\end{array}$ & $1,8-2,4$ & $0,61-0,81$ & $0,44-0,51$ & $0,40-0,64$ & $0,04-0,11$ & $0,86-0,95$ \\
\hline $\begin{array}{l}\text { W. Yan et al., 2015 } \\
\text { [26]* }\end{array}$ & $1,70-2,10$ & $0,93-1,50$ & - & $0,45-0,50$ & $0,04-0,18$ & \\
\hline $\begin{array}{l}\text { K.J. Jankowski et } \\
\text { al., 2016 [17] }\end{array}$ & $2,26-2,29$ & $0,60-0,68$ & $0,54-0,57$ & $0,39-0,61$ & $0,17-0,18$ & $1,49-1,67$ \\
\hline $\begin{array}{l}\text { S.I. Lastochkina, } \\
\text { 2017 [27] }\end{array}$ & $1,63-2,44$ & - & - & $0,36-0,56$ & - & - \\
\hline $\begin{array}{l}\text { l. Jaskulska et al., } \\
2018[28]\end{array}$ & - & $0,69-0,73$ & $0,77-0,81$ & - & - & - \\
\hline $\begin{array}{l}\text { X.-X. Chen et al., } \\
2019 \text { [29]* }\end{array}$ & - & $0,55-0,94$ & - & - & $0,47-1,44$ & -- \\
\hline $\begin{array}{l}\text { L.M. Mikhalska et } \\
\text { al., 2019 [18] }\end{array}$ & - & $0,56-0,73$ & $0,38-0,50$ & - & - & - \\
\hline
\end{tabular}

Note. Recalculated from $P$ to $P_{2} \mathrm{O}_{5}$ by a factor of 2.29, from $\mathrm{K}$ to $\mathrm{K}_{2} \mathrm{O}$ by a factor of 1.20.

The variability of the micronutrient composition of grain and straw was higher than the variability of NPK (Table 4). Zinc, iron and manganese accumulation in grain were the most stable indicators, and their data distribution was closest to normal. The content of cobalt in grain and iron in straw were the least stable, with a significant asymmetry of histograms of distribution towards smaller values. Given the significant fluctuations in the content of micronutrients and the rather asymmetric data distribution, we consider it more correct to use as normative not arithmetic mean, but geometric means, which are (mg/kg): for grain - $\mathrm{Zn} \mathrm{19}$, Co 0.51, Fe 37 , Mn 30, Cu 2.1, for straw - Zn 1.8, Co 0.52, Fe 27, Mn 12, Cu 0.6.

\section{Main statistics of NPK content in grain and straw in $2016-2020(n=167)$}

\begin{tabular}{|c|c|c|c|c|c|c|}
\hline \multirow[b]{2}{*}{$\begin{array}{l}\text { Part of } \\
\text { yield }\end{array}$} & \multirow[b]{2}{*}{ Micronutrients } & \multicolumn{4}{|c|}{ Micronutrients content, \% } & \multirow[b]{2}{*}{$\begin{array}{l}\text { Coefficient } \\
\text { of variation }\end{array}$} \\
\hline & & mean & minimum & maximum & $\begin{array}{l}\text { standard } \\
\text { error }\end{array}$ & \\
\hline \multirow{5}{*}{ Grain } & $\mathrm{Zn}$ & 19,59 & 11,58 & 31,34 & 3,80 & 19 \\
\hline & Co & 0,76 & 0,04 & 3,36 & 0,67 & 88 \\
\hline & $\mathrm{Fe}$ & 38,19 & 18,64 & 63,63 & 8,82 & 23 \\
\hline & $\mathrm{Mn}$ & 30,76 & 6,13 & 49,22 & 6,76 & 22 \\
\hline & $\mathrm{Cu}$ & 2,30 & 0,36 & 5,80 & 1,05 & 46 \\
\hline \multirow{5}{*}{ Straw } & $\mathrm{Zn}$ & 2,31 & 0,09 & 9,46 & 1,63 & 70 \\
\hline & Co & 0,76 & 0,01 & 2,67 & 0,60 & 78 \\
\hline & $\mathrm{Fe}$ & 49,55 & 3,21 & 251,54 & 57,73 & 117 \\
\hline & $\mathrm{Mn}$ & 17,73 & 0,86 & 78,32 & 13,78 & 78 \\
\hline & $\mathrm{Cu}$ & 0,79 & 0,01 & 3,47 & 0,57 & 73 \\
\hline
\end{tabular}

\section{Conclusions}

The content and ratio of nutrients in grain and straw of winter wheat of modern varieties differ from those that were in production before.

For growing winter wheat of modern foreign and Ukrainian breeding during 2016-2020 on soils of different genesis and level of nutrient supply, the average nutrients uptake from 1 ton of grain are: $\mathrm{N}-21.6 \mathrm{~kg}, \mathrm{P}_{2} \mathrm{O}_{5}-$ $6.5 \mathrm{~kg}, \mathrm{~K}_{2} \mathrm{O}-4.6 \mathrm{~kg}$, and from 1 ton of straw $-4.9 \mathrm{~kg}, 1.1 \mathrm{~kg}$ and $17.5 \mathrm{~kg}$, respectively.

The average values of micronutrients content in the final production of winter wheat are ( $\mathrm{mg} / \mathrm{kg})$ : for grain - Zn 19, Co 0.51, Fe 37, Mn 30, Cu 2.1, for straw - Zn 1.8, Co 0.52, Fe 27, Mn 12, Cu 0.6.

\section{References}

1. Barraclough, P.B., Lopez-Bellido, R., \& Hawkesford, M.J. (2014). Genotypic variation in the uptake, portioning and remobilization of nitrogen during grain-filling in wheat. Field Crops Research, 156, 242248. doi: 10.1016/j.fcr.2013.10.004.

2. Hamnér, K., Weih, M., Eriksson, J., \& Kirchmann, H. (2017). Influence of nitrogen supply on macro- and micronutrient accumulation during growth of winter wheat. Field Crops Research, 213, 118-129. doi: 10.1016/j.fcr.2017.08.002

3. Ahrends, H.E., Eugster, W., Gaiser T., Rueda-Ayala, V., Hüging, H., Ewert, F., \& Siebert, S. (2018). Genetic yield gains of winter wheat in Germany over 100 years (1895-2007) under contrasting fertilizer applications. Environmental Research Letters, 13, 104003. doi: 10.1088/1748-9326/aade12.

4. Klymashevskyi, E.L. (1991). Henetycheskyi Aspekt Myneralnoho Pytanyia Rastenyi [The Genetic Aspect of the Mineral Nutrition of Plants]. Moscow: Agropromizdat. [In Russian]. 
5. Sugár, E., Berzsenyi, Z., Bónis, P., \& Árendás, T. (2017). Growth analysis of winter wheat cultivars as affected by nitrogen fertilization. Die bodencultur: Journal of Land Management, Food and Environment, 68, 1, 57-70. doi: 10.1515/boku-2017-0005.

6. Abd El-Razek, U.A., El-Sheshtawy, A.A. (2013). Response of Some Wheat Varieties to Bio and Mineral Nitrogen Fertilizers. Asian Journal of Crop Science, 5, 200-208. doi: 10.3923/ajcs.2013.200.208.

7. Kariuki, S.K., Zhang, H., Schroder, J.L., Edwards, J., Payton, M., Carver, B.F., Raun, W.R., \& Krenzer, E.G. (2007). Hard Red Winter Wheat Cultivar Responses to a pH and Aluminium Concentration Gradient. Agronomy Journal, 99, 88-97. doi: 10.2134/agronj2006.0128.

8. Zheng, Y., Wang, Z., Sun, X., J.A., Jiang, G., \& Li, Z. (2008). Higher salt tolerant winter wheat cultivars relieve senescence at reproductive stage. Environmental and Experimental Botany, 62, 2, 129-138. doi: 10.1016/j.envexpbot.2007.07.011.

9. Oyiga, B.C., Sharma, R.C., Shen, J., Baum, M., Ogbonnaya, F.C., Léon, J., \& Ballvora, A. (2016). Identification and Characterization of Salt Tolerance of Wheat Germplasm Using a Multivariable Screening Approach. Journal of Agronomy and Crop Science, 202, 472-485. doi: 10.1111/jac.12178.

10. Proekt Postanovy Kabinetu Ministriv Ukrayiny «Normatyvni pokaznyky vynosu pozhyvnyh rechovyn urozhayem silskogospodarskyh kultur [Draft Resolution of the Cabinet of Ministers of Ukraine: "Normative indicators of nutrient removal by harvest of agricultural crops.]. Retrived from https://agro.me.gov.ua/ua/npa/proekt-postanovi-kabinetu-ministriv-ukraini-pro-zatverdzhennyanormativnikh-pokaznikiv-vinosu-pozhivnikh-rechovin-urozhaem-silskogospodarskikh-kultur Ukrainian].

11. Hospodarenko, G.M. (2015). Systema zastosuvannya dobryv: navch. posibnyk. [Fertilizer application system: manual textbook]. Kyiv: TOV «SIK GRUP Ukraine». [In Ukrainian].

12. Balyuk, S. A., Grekov, V. O., Lisovyi, M. V., \& Komarysta, A. V. (2011). Rozrahunok balansu gumusu i pozhyvnyh rechovyn u zemlerobstvi Ukrayiny na riznyh rivnyah upravlinnya. [Calculation of the balance of humus and nutrients in agriculture of Ukraine at different levels of management]. Khatrkiv: Miska drukarnya. [In Ukrainian].

13. Gorodniy, M.M., Gryshhenko, O.V., \& Gengalo, O.M. (2013). Vykorystannya novyh dobryv iz shyrokym spektrom diyi. [Use of new fertilizers with a wide range of action.]. Scientific papers of Institute of Bioenergy Crops and Sugar Beet, 17, II, 36-43. [In Ukrainian].

14. Miroshnychenko, M.M., \& Fateyev, A.I. (2008). Agrogeohimiya mikroelementiv $\vee$ gruntah Ukrayiny. [Agrogeochemistry of microelements in soils of Ukraine]. Agrochemistry and Soil Science. Special issue before VIII congress of USSSA, Book 1, 98-107. [In Ukrainian].

15. Garvin, D.F., Welch, R.M., \& Finley, J.W. (2006). Historical shift in the seed mineral micronutrient concentration of US hard red winter wheat germplasm. Journal of the Science of Food and Agriculture, 86, 2213-2220. doi: 10.1002/isfa.2601.

16. Svečnjak, Z., Jenel, M., Bujan, M., Vitali, D., \& Dragojevic, I.V. (2013). Trace element concentration in the grain of wheat cultivars as affected by nitrogen fertilization. Agricultural and Food Science, 22, 445451.

17. Jankowski, K.J., Hulanicki, P.S., Sokólski, M., Hulanicki, P., \& Dubis, B. (2016). Yield and quality of winter wheat (Triticum aestivum L.) in response to different systems of foliar fertilization. Journal of Elementology, 21, 3, 715-728. doi: 10.5601/ jelem.2015.20.4.1036.

18. Mykhalska, L.M., Shwartau, V.V., Sanin, O.Yu., \& Tretyakov V.O. (2019). Vmist neorganichnyh elementiv u zerni pshenyci ozymoyi za kontrolyuvannya fuzariozu. [Content of inorganic elements in winter wheat grain when controlling fusarium]. Plant Physiology and Genetics, 51, 5, 399-414. doi: 10.15407/frg2019.05.399. [In Ukrainian].

19. Miroshnychenko, M.M., Zvonar, A.M., Panasenko, Ye.V., \& Leonov, O.Yu. [2020]. Nadhodzhennya elementiv zhyvlennya do roslyn pshenyci ozymoyi riznyh sortiv u kontrastni za pogodnymy umovamy roky [Nutrient supply to different varieties of winter wheat in contrast weather conditions]. Agrochemistry and Soil Science, 89, 51-62. doi: 10.31073/acss89-06. [In Ukrainian].

20. Clarke, J.M., Campbell, C.A., Cutforth, H.W., DePauw, R.M., \& Winkleman, G.E. (1990). Nitrogen and Phosphorus uptake, translocation, and utilization efficiency of wheat in relation to environment and cultivar yield and protein levels. Canadian Journal of Plant Science, 70, 965-977.

21. Khan, P., Imtiaz, M., Shah, S.K.H., Nizanuddin, Memon, M.Y., \& Siddique, S. (2008). Effect of different Nitrogen and Phosphorus ratios on the perforemance of wheat cultivar "Khirman". Sarhad Journal of Agriculture, 24, 2, 233-239.

22. Ivanina, V.V. Biologizaciya udobrennya kul tur u sivozminax. (2016). [Biologization of fertilization in crop rotations]. Kiyv: LLC «CP «KOMPRINT». [In Ukrainian].

23. Kovačević, V., Kadar, I., Rastija, M., \& Sudar, R. (2013). Impacts of NPK fertilization on chemical composition of wheat grain (pp. 510-514). Proceedings of the 48th Croatian and 8th International Symposium on Agriculture. (Dubrovnik, Croatia, 17-20 February 2013). Dubrovnik.

24. Rangel, Y.A., Eriksson, J., Fägerlind, K., Liew, J., Ländel,I G., \& Wahlstedt, G. (2013). Estimating the content of nitrogen and phosphorus in agricultural products in Sweden. Winter wheat, spring barley, oats, crop residues and ley crops. 2013. SCB, Stockholm 08-50694000. Grant No 40701.2011.0032011.560.

25. Filimontuk, Ya.S. (2014). Osoblyvosti mineralnogo zhyvlennya pshenyci ozymoyi zalezhno vid 
fosfatnogo rezhymu gruntu. [Features of mineral nutrition of winter wheat depending on the phosphate regime of the soil]. Bulletin of Agricultural Science, 11, 68-71. [In Ukrainian].

26. Yan, W., Zhong, Y., \& Shangguan, Z. (2015). The relationships and sensibility of wheat C:N:P stoichiometry and water use efficiency under nitrogen fertilization. Plant, Soil and Environment, 61, 5, 201-207. doi: 10.17221/28/2-15-PSE

27. Lastochkina, S.I. (2017). Vlyyanye raznih doz azotnogo pytaniya na soderzhanye i nakoplenye osnovnih elementov myneralnogo pytaniya $v$ byomasse ozymoi pshenyczi, vozdelivaemoi na dernovo-palevopodzolystoi legkosuglynystoi pochve. [Influence of different doses of nitrogen nutrition on the content and accumulation of the main elements of mineral nutrition in the biomass of winter wheat cultivated on soddy-pale-podzolic light loamy soil]. Bulletin of Bryansk State Agrarian University, 5(63), 3-8. [In Russian].

28. Jaskulska, I., Juskulski, D., Galezewski, L., Knapowski, T., Kozera, W., \& Waclawowicz, R. (2018). Mineral Composition and Baking Value of the Winter Wheat Grain under Varied Environmental and Agronomic Conditions. Hindawi Journal of Chemistry. doi: 10.1155/2018/5013825

29. Chen, X.X., Zhang, W., Liang, X.Y., Liu, Y.M., Xu, S.J., Zhao, Q.Y., \& Zou, C.Q. (2019). Physiological and developmental traits associated with the grain yield of winter wheat as affected by phosphorus fertilizer management. Scientific Reports, 9. doi: 10.1038/ s41598-019-53000-z. 